\section{Kulturarven \\ Danmark og UNESCOs Memory of the World Register}

afErland Kolding Nielsen, direktør, Det Kongelige Bibliotek, formand for den danske $\mathrm{Me}$ mory of the World-Komité

$\mathrm{F}$ Ns verdensorganisation for uddannelse, videnskab og kultur, UNESCO grundlagdes allerede i 1945 som en af de første organisationer i FN-systemet med hovedsæde i Paris. En af dens fornemste opgaver har siden været af skabe forståelse for beskyttelsen af verdens kultur- og naturarv og at sætte handling bag ideen. Det gør verdensorganisationen bl.a. gennem vedtagelse af konventioner og iværksættelse af handlingsprogrammer. Opgaverne varetages på nationalt plan bl.a. gennem nationale UNESCO-kommissioner, således også i Danmark.
I 1972 vedtoges Verdensarvskonventionen (World Heritage Convention) og i fortsættelse heraf oprettedes en Liste over Verdensarven (World Heritage List), hvorpå der siden 1978 efter nøje vurdering $\mathrm{i}$ internationalt perspektiv optages jordfaste kultur- og naturmindesmærker, der må vurderes som umistelige for jordens stater og folk. I alt er der ved udgangen af 2005 optaget mere end 800 mindesmærker, heraf 4 fra Danmark, nemlig Jellinghøjene med runestene og kirke (1994), Roskilde Domkirke (1995), Kronborg Slot (2000) og Ilulissat-Fjorden i Grønland (2004). Optagelse på listen er både vigtig og prestigefyldt og bidrager til at skabe bevidsthed i brede kredse om nødvendigheden af at beskytte for at kunne bevare vor fælles kulturarv over alt på jorden.

Parallelt hermed lancerede UNESCO i 1992 sit Memory of the Worldprogram $(\mathrm{MoW})$ for den skrevne og audiovisuelle kulturarv. Formålet er at skabe bevidsthed om, at det ligeledes er nødvendigt at beskytte og bevare de mange uerstattelige

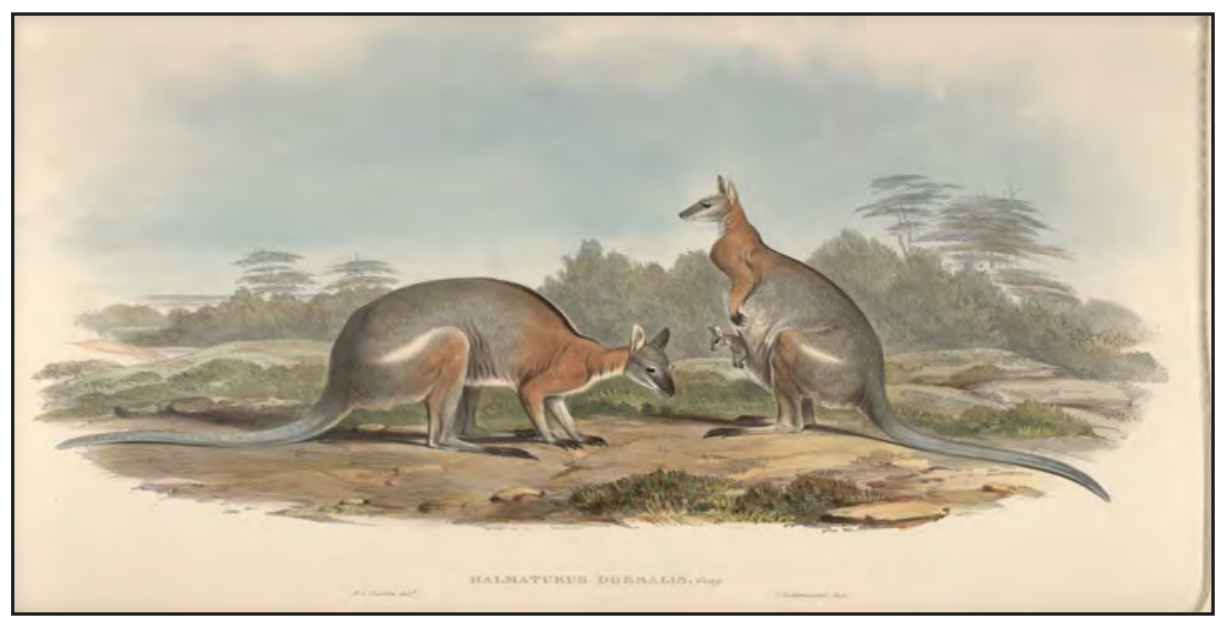

Den Classenske samling af naturhistoriske planchevarker. Nomineret til Memory of the World-listen 1997 John Gould: Mammals of Australia, bind 1-3, 1863 (Det Kongelige Bibliotek). 


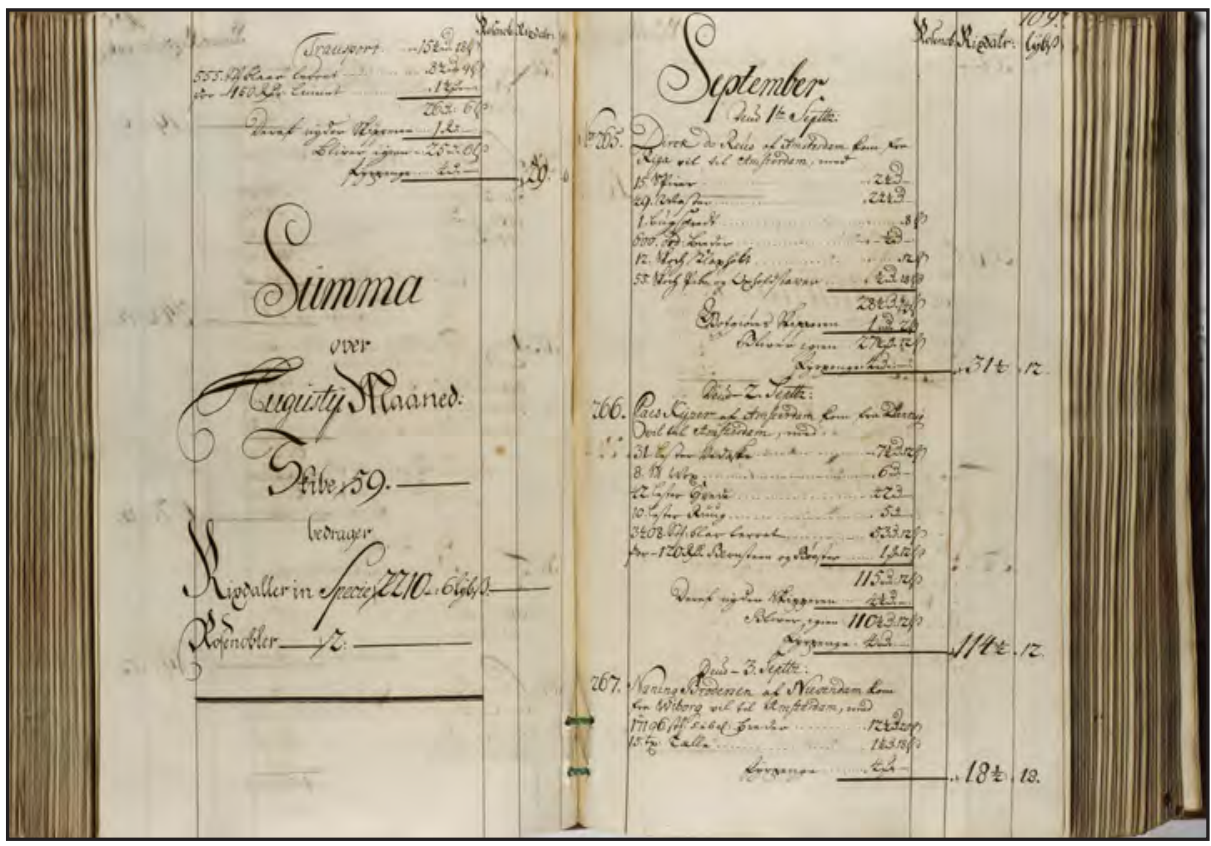

Øresundstoldregnskaberne. Nomineret til Memory of the World-listen 2006

Den 1. september 1735 kom skipper Dirck de Reus af Amsterdam forbi Helsingør pà vej fra Riga til Amsterdam. Han blev i regnskabet indfort under lobenummer 265. Hans ladning bestod af 15 spir, 49 master, 1 bovspryd, 600 ordinare bradder, 12 skok (à 30 styk) klapholt og 55 skok pibe- og oksestaver. Herfor skulle betales 281/2 rigsdaler og 14 skilling. Efter godtgørelse til skipperen og med fyrpenge blev der $31 \frac{1}{2}$ rigsdaler og 12 skilling at betale til tolderne i Helsingør. Oresundstoldregnskaberne rummer en totalregistrering i over 300 ar - indtil Sundtoldens afskaffelse i 1857 - af trafikken i et af verdens vigtigste gennemsejlingsfarvande (Rigsarkivet).

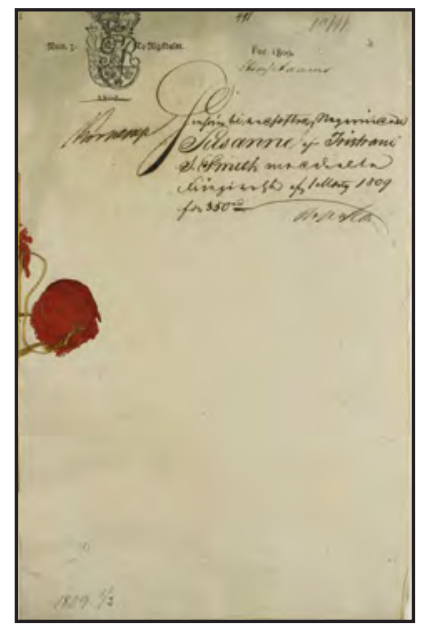

Vestindiske lokalarkiver. Nomineret til Memory of the World-listen 2006

Frigivelsesbrev for negerslave i Dansk Vestindien 1809. 'Negerinden' Susanne, som var ejet af Tristram S. Smith på St. Croix, blev for 250 rigsdaler købt fri. Andringen fik retsgyldighed ved at blive tinglast og indfort $i$ pantebogen ved retten $i$ Christianssted.

De tre små vestindiske øer Sankt Thomas, Sankt Jan og Sankt Croix udgjorde i et par hundrede àr en dansk koloni og oplevede en økonomisk blomstring mellem 1750 og 1850. Ved slaveriets afskaffelse $i 1848$ og fremkomsten af dampskibe og forbedrede kommunikationsmidler gik det ned ad bakke for Dansk Vestindien. I 1917 blev øerne købt af USA (Rigsarkivet). 


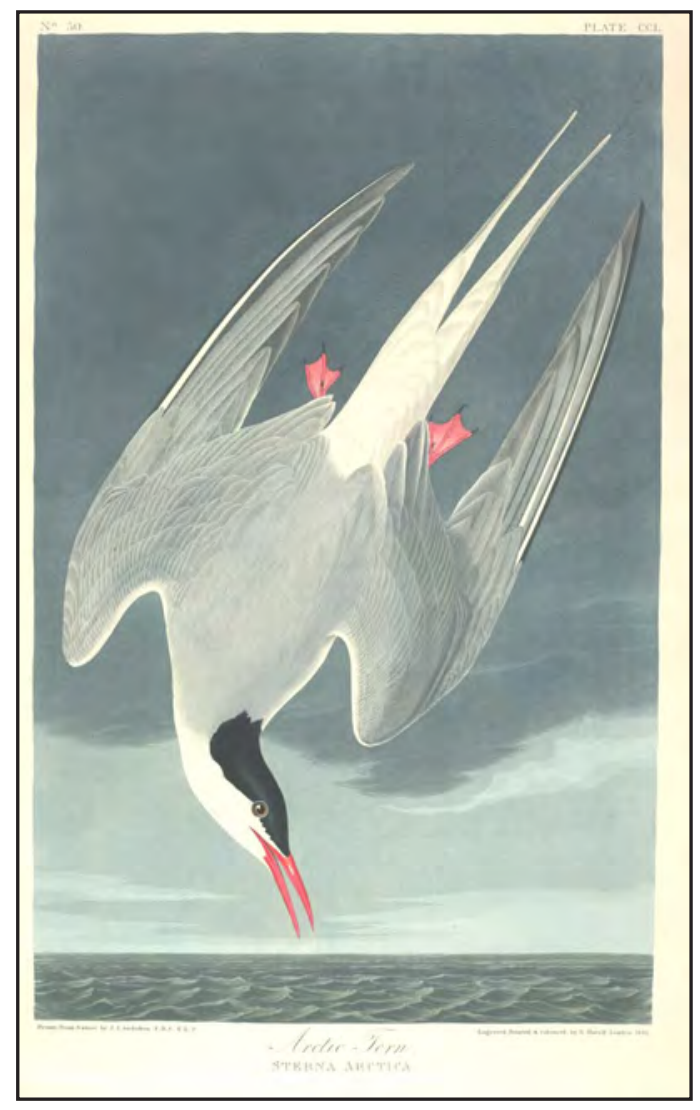

Den Classenske samling af naturhistoriske planchevarker. Nomineret til Memory of the World-listen 1997

Samlingens storste klenodie er Skandinaviens eneste eksemplar afJ.J. Audubon: Birds of America, bind 1-4, London 1827-32. Formatet er, hvad englanderne kalder elefant-folio. Det indeholder 435 plancher $i$ akvatinte som gengiver fuglene i naturlig storelse og i deres naturlige omgivelser. (Det Kongelige Bibliotek).

historiske dokumenter - den dokumentariske kulturarv - i biblioteker og arkivers samlinger verden over, som er truet af mange grunde og fra mange sider. Som en del af programmet blev der fra 1997 oprettet et Memory of the World Register, en fortegnelse over umistelige dokumenter, d.v.s. håndskrifter, bøger og audiovisuelle dokumenter, samt arkiver og bibliotekssamlinger af unik betydning verden over. Ved udgangen af 2005 omfatter fortegnelsen 120 værker eller samlinger fra 57 lande, rækkende fra film til klippeinskriptioner, fra lydoptagelser til fotografier, fra bøger og oldtidsmanuskripter til arkiver og avissamlinger. De er udvalgt efter nominering fra de enkelte lande, vurderes ud fra en række kriterier af en international rådgivende komité, der fra 1993 mødes hvert andet år, og beslutning om optagelse på fortegnelsen konfirmeres af UNESCOs generalsekretær.

MoW-programmets vision tager udgangspunkt $\mathrm{i}$, at verdens dokumentariske kulturarv tilhører os alle, derfor skal bevares og beskyttes for alle og være fuldt tilgængelig, f.eks. gennem digitalisering, for alle. I forlængelse heraf er programmets mission at skabe opmærksomhed om og forståelse for beskyttelsen af kulturarven og at stræbe efter universel og permanent adgang for 


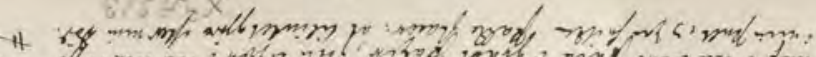

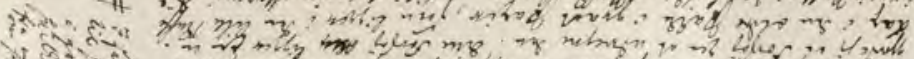

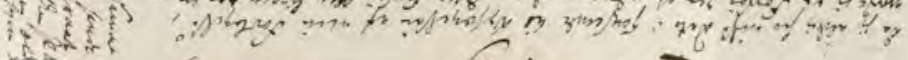

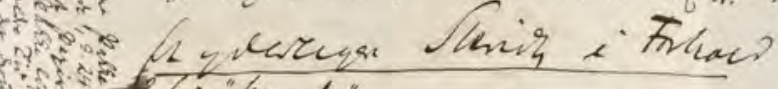

if in Li hewh:

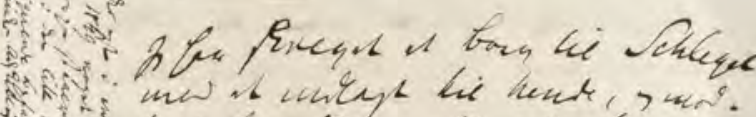

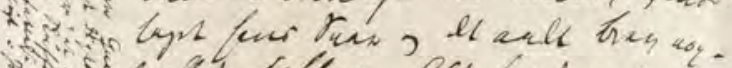

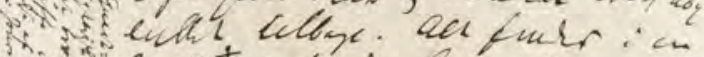

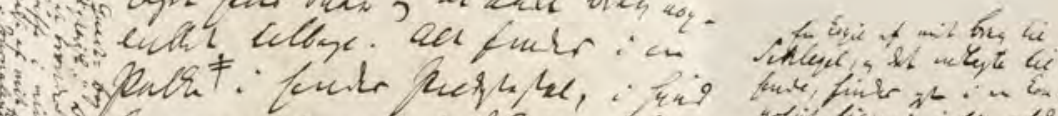

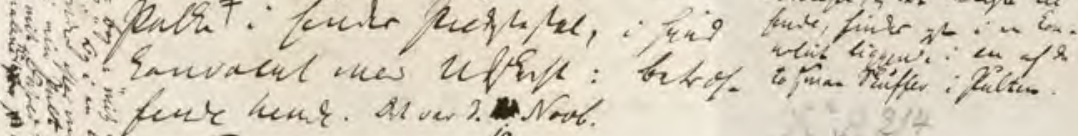

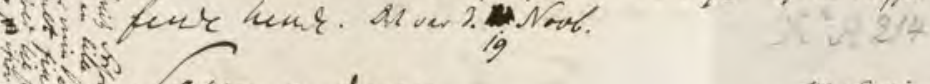

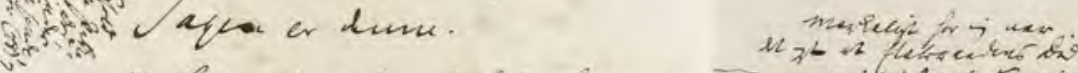

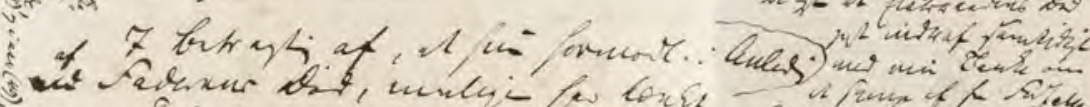

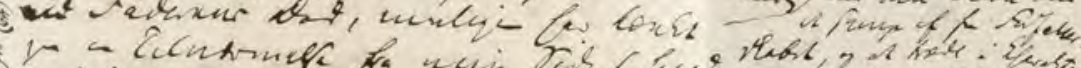

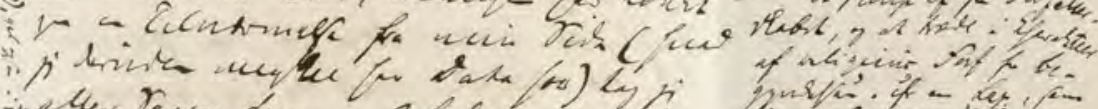

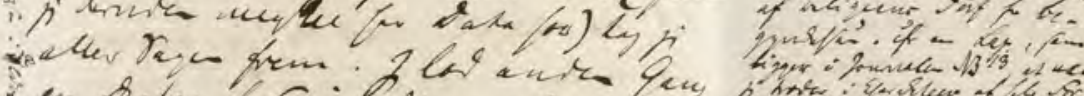

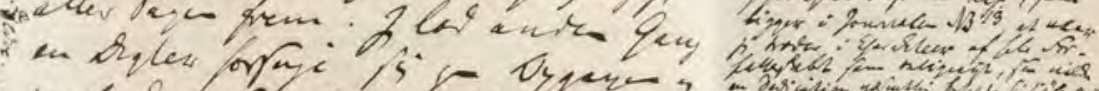

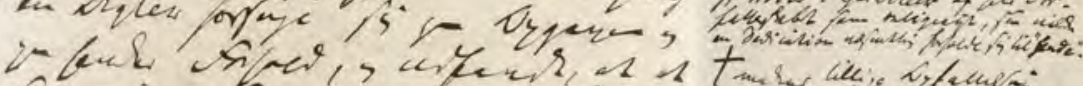

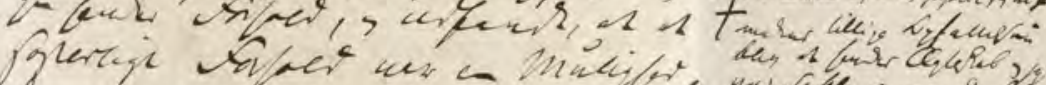

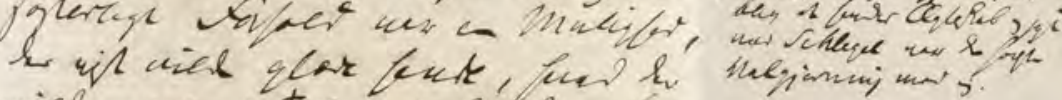

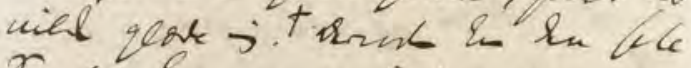
Dy lit fancue of igin, Mar cugas,

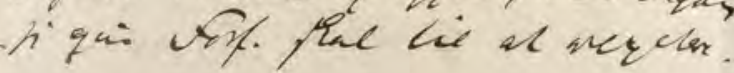

Søren Kierkegaard-arkivet. Optaget på Memory of the World-listen 1997

Arkivet omfatter Søren Kierkegaards varkmanuskripter, journaler, notesboger og lasepapirer, breve, biografiske dokumenter samt boger, der har tilhørt Kierkegaard. Fra journalen NB14, begyndelsen af optegnelse 44: Et yderligere Skridt i Forhold til 'hende' (Det Kongelige Bibliotek). 


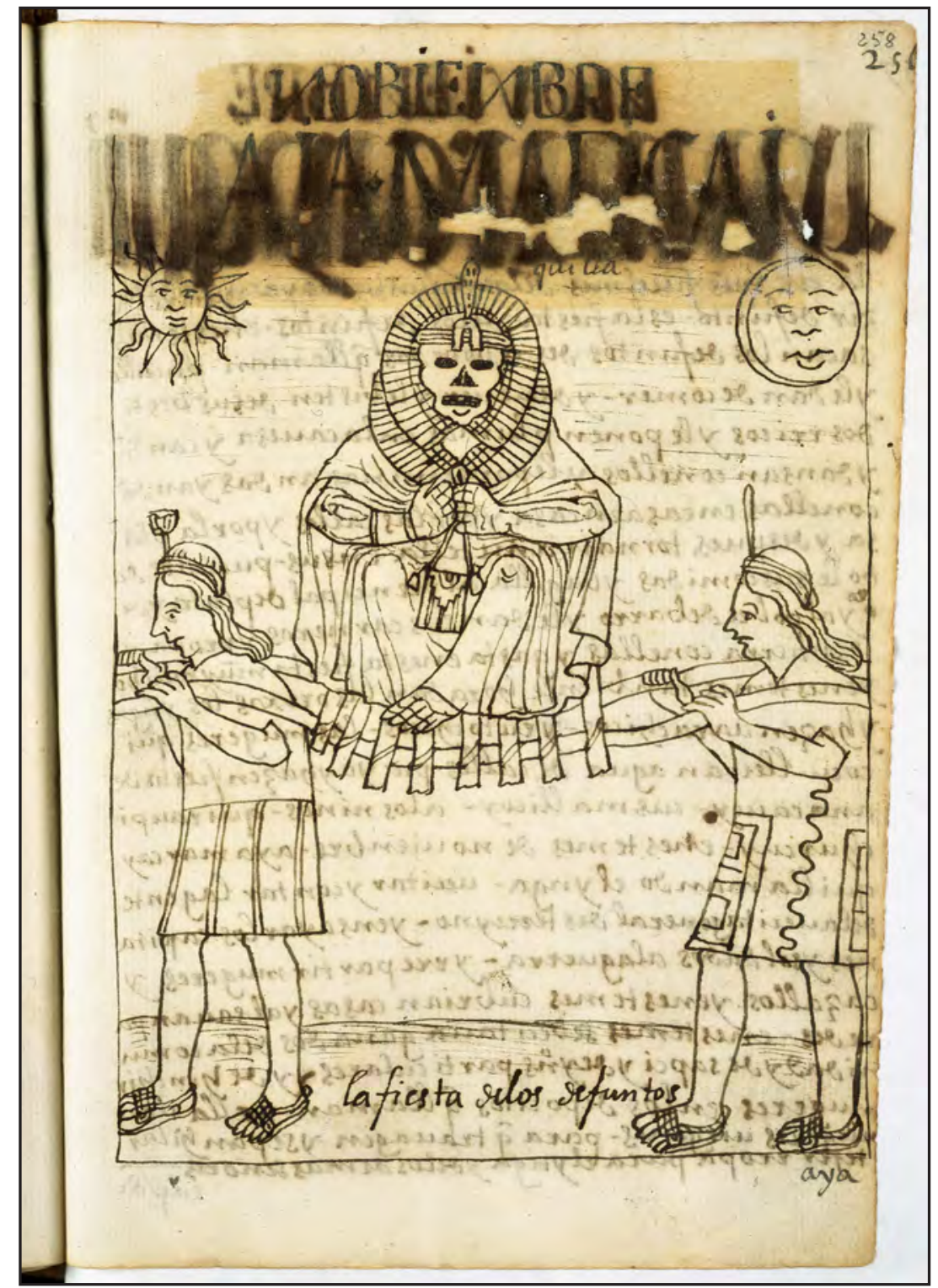

Guaman Pomas Inkakrønike. Nomineret til Memory of the World-listen 1997 \& 2006 Inkakrøniken indeholder et afsnit om årets måneder. Hver måned er illustreret med en tegning. November er den maned hvor de dode bares rundt.

Guaman Pomas Inkakrønike et af de berømteste håndskrifter i Det Kongelige Bibliotek. Varket blev til i det sydlige Peru 1600-1615. Det omfatter dels en beretning om Andes-regionens historie fra de aldste tider, dels en rakke kritisk-satiriske skildringer af kolonistyret, med forslag til gennemgribende reformer. Håndskriftet er forsynet med knap 400 helsides pennetegninger.(Det kongelige Bibliotek). 


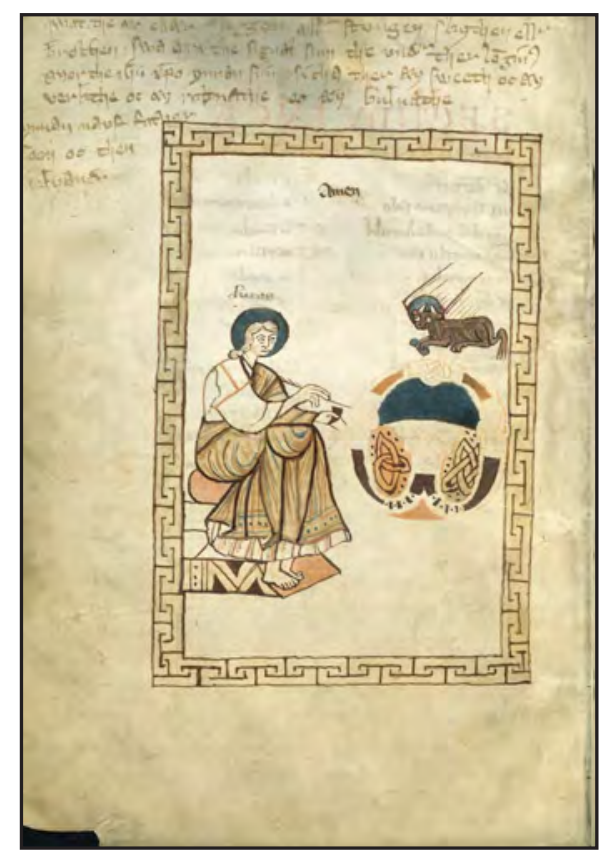

verdens befolkning til at se og opleve sine kulturskatte.

Danmark nominerede ved den første indkaldelse af forslag til optagelse på fortegnelsen i 199513 enkeltdokumenter, bog-, manuskript- og audiovisuelle samlinger samt arkiver fra de nationale kulturarvsinstitutioner, d.v.s. Det Kongelige Bibliotek (inkl. det daværende Danmarks Natur-og Lagevidenskabelige Bibliotek, sammenlagt med Det Kongelige Bibliotek i 2005), Rigsarkivet og Statsbiblioteket. Heraf optoges 4 , nemlig H.C. Andersens breve og manuskripter og Søren Kierkegaard Arkivet i Det Kongelige Bibliotek, en fornem specialsamling af og om den store svenske naturforsker og læge Carl von Linné (1707-1778) i Danmarks Natur- og Lægevidenskabelige Bibliotek samt arkiverne fra de danske oversøiske handelskompagnier i det 17. og 18. århundrede, i alt cirka 4.000 pakker og bind, der i dag befinder sig i Rigsarkivet.
Dalbybogen. Nomineret til Memory of the World listen 1997

Dalbybogen er blevet til $i$ anden halvdel af 1000tallet og antages at vare den aldste bevarede bog der er fremstillet $i$ Norden. Bogen indeholder de fire evangelier på latin. Teksten er skrevet med karolingiske bogstaver af en tranet hånd. Mindre rutineret er billederne af de fire evangelister og deres symboler. Dalbybogens evangelistsider har $i k k e$ de astetiske kvaliteter man kan finde $i$ samtidige håndskrifter fra andre dele af Europa, men det er bl.a. det der gør bogen så interessant. Som vidnesbyrd om bogkulturens forste skridt ind i Norden, om Nordens integration med det øvrige Europa (Det Kongelige Bibliotek).

Yderligere nomineret i 1995 blev Danmarks formentlig ældste bevarede bog, Dalbybogen, et evangeliehåndskrift fra ca. 1050-1100 (GKS 1325, 4o, Det Kongelige Bibliotek), der stammer fra Skåne, det eneste kendte fragment af Saxos manuskript til Gesta Danorum, fra ca. 1200, Angers-fragmentet (NKS 869g, 4o, Det Kongelige Bibliotek), der blev fundet 1863 som bogbindsfyld i 1400-tals håndskrift i et bibliotek i den franske by Angers og erhvervet af Danmark ved bytte i 1878,3 originale håndtegnede kort over Grønland, biskop Hans Resens fra 1605, Hans Egedes fra 1737 , og Høeg Hagens fra 1907, Den Classenske Samling af naturhistoriske plancheværker fra det 18. og 19. århundrede, 1867-68 overtaget af Universitetsbiblioteket, dettes egen samling af naturvidenskabelige og medicinske værker af verdensberømte danske naturvidenskabsmand, Danmarks ældste lydoptagelser, de såkaldte Rubenvalser, opta- 
Hans Egedes Grønlandskort 1737. Nomineret til Memory of the World listen 1997 Hans Egedes kort over den sydlige del af Gronland er baseret pa to rekogno-

sceringsrejser i somrene 1723 og 1724 på Vestkysten, mens Ostkysten udelukkende bygger på oplysninger fra sagaerne. Kortet blev tegnet efter Hans Egedes hjemkomst til Kobenhavn i 1735 (Det Kongelige Bibliotek).

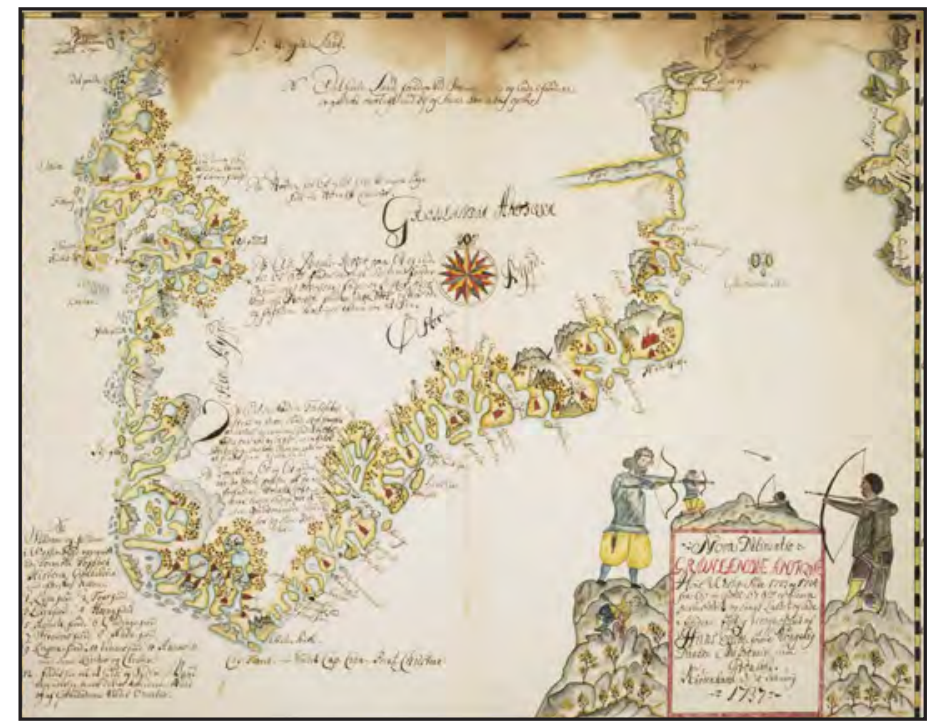

H.C. Andersens breve \& manuskripter. Optaget på Memory of the World-listen 1997

En af Det Kongelige Biblioteks mest betydningsfulde samlinger er H.C. Andersens manuskripter til eventyr, digte, romaner og dramatiske verker, dagboger og almanakker. Samlingen indeholder også breve og mange papirklip (Det Kongelige Bibliotek).

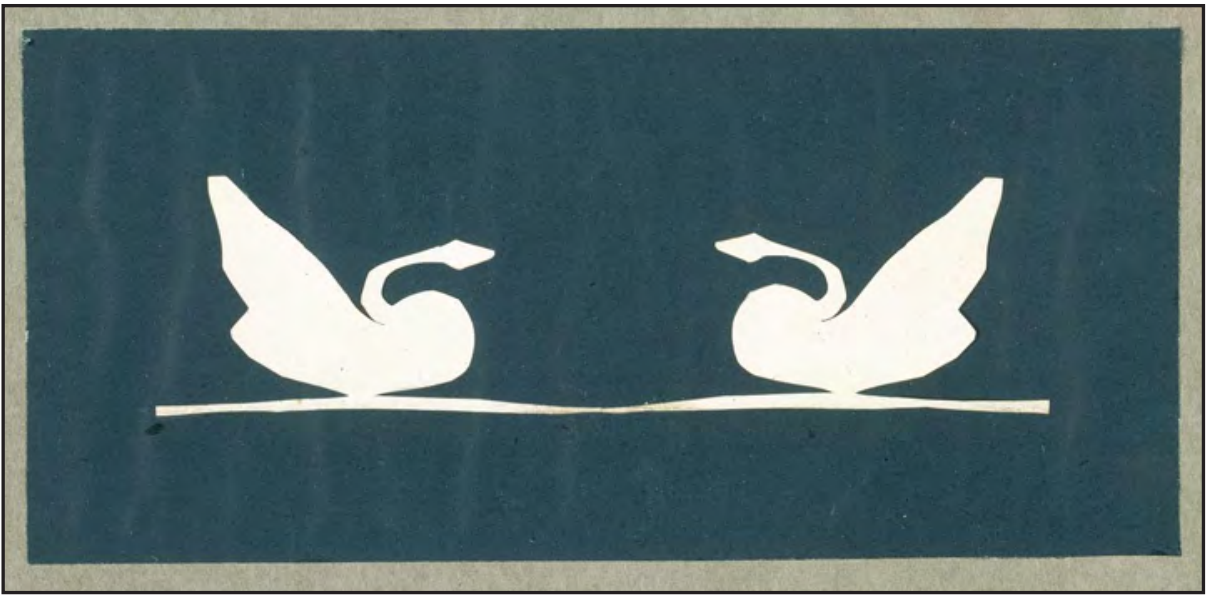




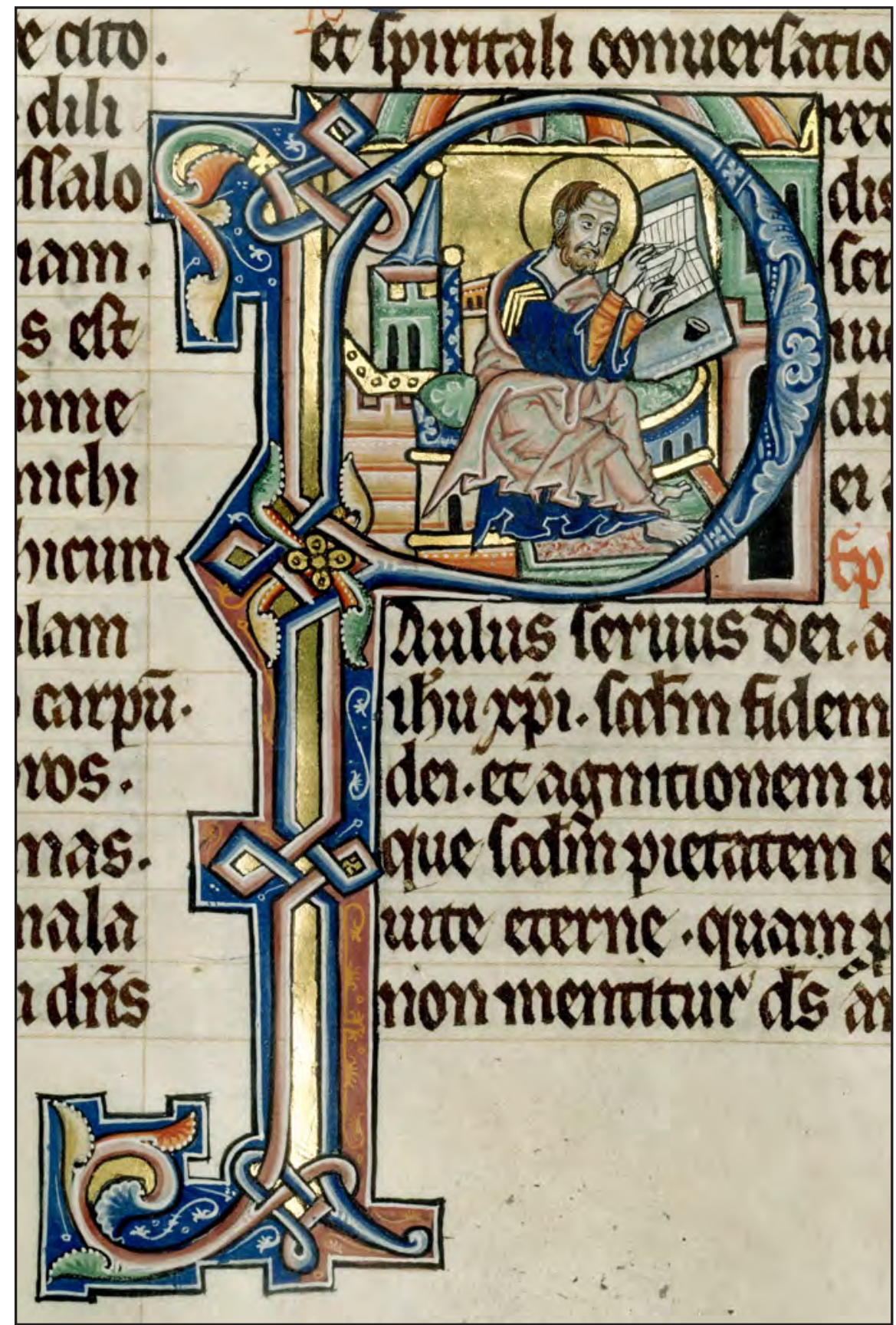

Illustration fra Hamburgbibelen, der viser et led i bogfremstillingen (Det Kongelige Bibliotek). 
get i København 1889-1897 (nu i Statsbiblioteket) samt Anker Kirkeby-samlingen af lydoptagelser 1913-ca. 1940. Disse nomineringer nød ikke fremme på verdensplan, men blev ud fra det mere lokale betydning henvist til en national MoW-fortegnelse.

\section{I foråret 2006 har Memory of the}

World-Komitéen, nedsat 1999 af Den Danske UNESCO-Nationalkommission, nomineret yderligere 3 dokumenter og arkiver, nemlig en af Det Kongelige Biblioteks absolut største skatte, den sydamerikanske indianer og inkaætling Guaman Pomas Inkakrønike fra 1600-1615 (GKS 2232, 40), Øresundstoldregnskaberne fra det 16. århundrede og frem til 1857, det almenhistoriske danske kildekompleks, der nyder størst international bevågenhed (Rigsarkivet). Endelig de vestindiske lokalarkiver fra den danske lokalforvaltning af kolonierne på de små caribiske øer St. Thomas, St. Jan og St. Croix fra 1755-1917, i alt 9.647 pakker og bind, som fylder ca. 800 hyldemeter i Rigsarkivet, et kildemateriale, der i mange henseender er af international betydning ikke mindst p.g.a. bevaringssituationen i området. De nomineret af Rigsarkivet i samarbejde med National Archives, Washington.

I 2008 agter Det Kongelige Bibliotek at nominere broder Bertoldus' bibel, også kaldet Hamburg-biblen efter dens proveniens, et enestående bibelhåndskrift i 3 statelige foliobind fra 1255, der er rigt illustreret gennem illuminerede begyndelsesbogstaver, initialer, hvorigennem skriveren Karolus højest usædvanligt bl.a. viser hele den middelalderlige bogproduktionsproces.

Som det ses, nominerer de enkelte lande værker, dokumenter og samlinger ud fra unikitets- og betydningskriterier uanset proveniens, idet mange dokumenters nuværende opholdssted er udtryk for en ofte lang og uransagelig vandringsproces. Det er

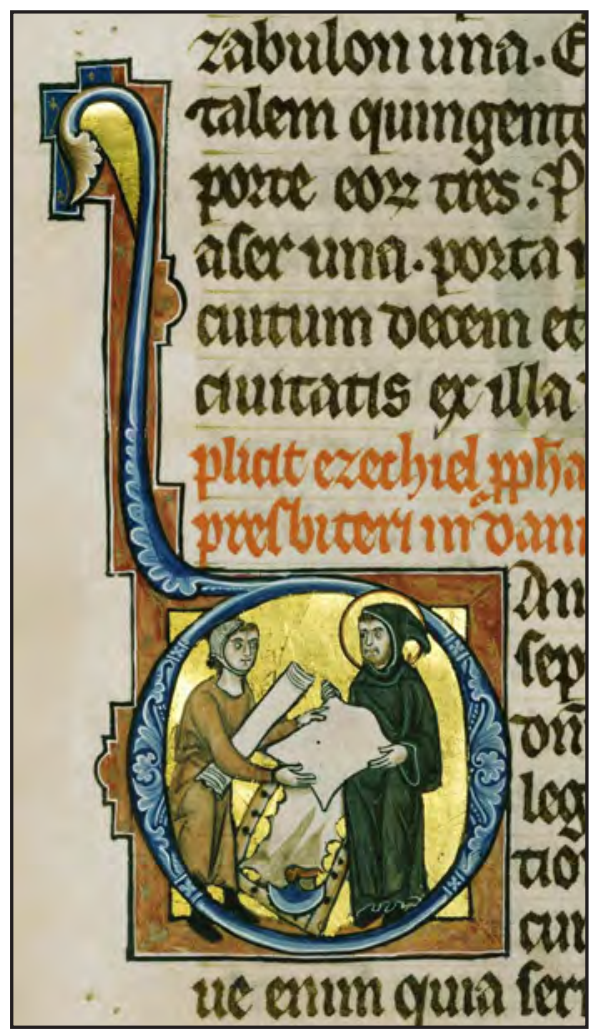

Illustration fra Hamburgbibelen, der viser et led $i$ bogfremstillingen (Det Kongelige Bibliotek).

således et udslag af skæbnens tilfældigheder, at f.eks. den vigtigste kilde til Inkaernes historie før Pizarros erobring af Inkariget i 1532 ligger i Det Kongelige Biblioteks sikringsboks.

Nationalkommissionen, MoWKomitéen og Det Kongelige Bibliotek har taget anledning i den nye nomineringsrunde til at vise alle de genstande - for samlinger naturligvis i udvalg - som Danmark har fået optaget på eller nomineret til det internationale Memory of the World Register for landets befolkning i sommeren 2006 som en del af en større udstilling i Diamanten over temaet „Trusler og Tyvekoster“. Det 
er første gang, dette sker, og det er således første gang, offentligheden får mulighed for at se og opleve en række af de genstande, der også i et internationalt perspektiv udgør en umistelig del af Danmarks kulturarv.

Til udstillingen har Det Kongelige Bibliotek udgivet en meget smuk bog ${ }^{1}$ med dansk/engelsk paralleltekst med titlen Danmark \& UNESCOs Memory of the World Register, redigeret af udstillingsredaktøren, forskningsbibliotekar, dr. phil. Karen Skovgaard-Petersen og bekostet af Den Dan-

Note

1 Danmark o UNESCOs Memory of the World Register/ Denmark \& Unesco's Memory of the World Register. Red. /edited by Karen Skovgaard-Petersen under medvirken af / in collaboration with Erland Kolding Nielsen og /and Sofie Lene Bak. Oversættelse / Translation: Vibeke Cranfield. Layout: Henriette Willerup. Udg. af / Published by Det Kongelige Bibliotek og Den Danske UNESCO Nationalkommission i samarbejde med Rigsarkivet og Statsbiblioteket. København / Copenhagen, 2006, 62 ss. Ill. Kr. 90,- ske UNESCO-Nationalkommission og Det Kongelige Bibliotek, der rummer en kortfattet beskrivelse med illustrationer af både de dokumenter og samlinger, der er optaget $i$ fortegnelse, og dem, der er blevet nomineret, men ikke optaget. De enkelte værk- eller samlingsbeskrivelser er skrevet af specialister fra de medvirkende institutioner. Tilsammen giver de et indblik i tankegangen bag og indholdet $\mathrm{i}$ ideen om fastholde verdens folkeslag på deres kollektive hukommelsethe Memory of the World. 